\title{
将来社会経済シナリオ下での SCGE モデルによる道路投資評価
}

An Evaluation Method of the Transport Project by SCGE under the Future Social Economic Scenarios*

小池淳司 $^{* *} \cdot$ 右近崇 $^{* * *} \cdot$ 宮下光宏 $^{* * * *} \cdot$ 佐藤尚 $^{* * * * *}$ By Atsushi KOIKE ${ }^{* *}$, Takashi UKON ${ }^{* * *}$, Mitsuhiro MIYASHITA ${ }^{* * *}$ and Takashi SATO $^{* * * *}$

\section{1. はじめに}

土木計画学の分野においても経済学的手法を用いた公 共政策評価分析手法が一般化している. なかでも，ワル ラス体系を忠実に再現した，応用一般均衡分析（以下， CGE分析）は交通整備事業に代表される社会基盤計画の評 価手法として広く用いられてきている゙.

その理由は以下のようにまとめられる. 1)経済理論と 整合的な便益の計測と同時に各種社会経済変数を知るこ とが可能である. (2)完全競争市場だけでなく税による歪 みまたは不完全競争を想定した経済下での便益評価が可 能となる. (3)応用一般均衡モデルが社会経済構造を忠実 に表現可能であるため，交通整備以外の公共政策評価が 同一のフレームで可能である. (4)さらに, 将来の社会経 済変化を経済理論と整合的に考慮することが可能である. 本研究では，この特徵の 4 番目である将来の社会経済環 境変化（以下, 将来社会経済シナリオ）を考慮した道路 投資の便益評価の感度分析を行うことを目的としている 2). 一方，この将来経済シナリオをCGE分析に適応した 例は, Nordhausら3)に代表される動学的CGEで用いられ る手法である. そこでは，人口成長・技術進歩などを将 来経済シナリオとして感度分析を行っているが, 非空間 CGEあり, 空間的分析を行うことができない. また, 本 研究が取り扱うような, 社会経済シナリオが混雑という 外部不経済性を発生するという現象を取り扱うことがで きない

具体的には，将来における人口滅少シナリオおよび東 アジア地域の経済成長シナリオを対象として, 従来の空 間的一般均衡モデルにこれら将来社会経済シナリオの影 響をどのようにモデル化し，そして，実証分析を実施す るのかの方法論を提案する. そして，道路交通整備を例 に，シナリオの考慮により便益の総額および便益の地域

*キーワード:整備効果計測法, 公共事業評価法

**正員, 工博, 鳥取大学工学部社会開発システム工学科 (鳥取市湖山町南 4-101，e-mail: koike@sse.tottori-u.ac.jp)

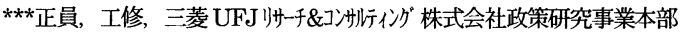
(名古屋市中区錦 3-20-27，e-mail: takashi.ukon@murc.jp）

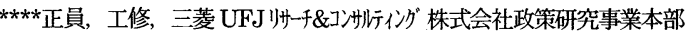
(名古屋妕区錦320-27, email mitsuhiromiyashita@murc.jp) *****正員, 工修, 三菱UFJリ州\&さ洲行仿 株式会社政策研究事業本部 (名古屋市中区錦 3-20-27, e-mail: takashi.sato@murc.jp)
間帰着構造にどのような影響があるのかを考察する.

まず，人口減少シナリオでは，生産人口変化を外生要 因と考え，生産における労働の初期保有量の減少をシナ リオとして考慮することとする. 一方, 東アジアの経済 成長シナリオでは, 中国の経済成長を外生要因として, それに伴う国内交易の増加量を算出し,その結果から QV 式を用いて計測される，道路混雑による所要時間の変化 を考慮することで, その影響を考慮することとする. す なわち，道路投資の効果は，人口減少シナリオでは便益 評価值を低くさせ，一方，東アジアの経済成長シナリオ では便益評価を高くさせることとなる. 本研究ではその 程度がどれほどであるかを実証分析から明らかにする.

以下，まず，本研究で取り扱う空間的応用一般均衡乇 デルの構造を示し, 将来社会経済シナリオのモデル化手 法，そして，関西大環状道路の整備を対象とした実証分 析を示す.

\section{2. モデルの構築}

（1）社会経済モデルと前提条件

図-1 に示す社会経済モデルを想定し，以下の仮定を設 ける.

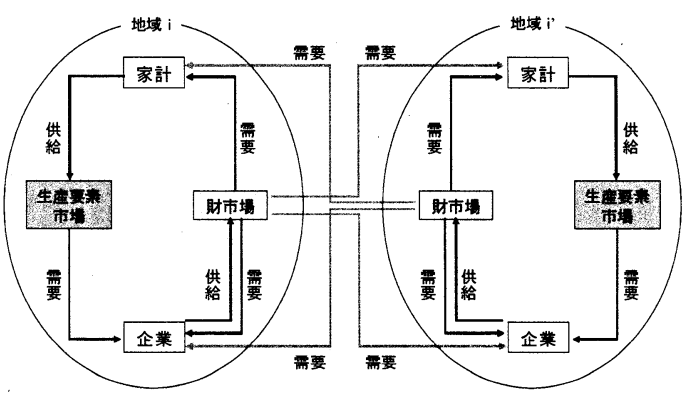

図-1＼cjkstart社会経済モデルの概略

(1) $I$ 個に分割された空間を考える.

(2)各地域には，アクティビティベースの $J$ 個の企業と代 表的世帯が存在する.

(3)財市場は地域に開放されているのに対して, 生産要素 市場は地域内で閉じている。

(4)各財については，消費地から見れば同一商品でも，生 
産地が異なればまったく異なる財として取り扱い，消 費地側では合成財として取り扱うという Armington 仮定 を前提とする.

(5)経済は長期均衡状態にあるものとする.

(6)生産される財により輸送費用が支払われるものとし， アイスバーグ型の交通抵抗を用いる.

（2）企業の行動モデル

各地域にはアクティビティベースの $J$ 個の企業が存在 し, 地域 $i$ に立地し $j$ 財を生産する企業は労㗢, 資本, 社 会資本, 自地域と他地域で生産された中間投入財により構 成される生産要素を用いて図-2 に示すようなネスティッ ド型の生産構造技術を用いて生産を行うとする.

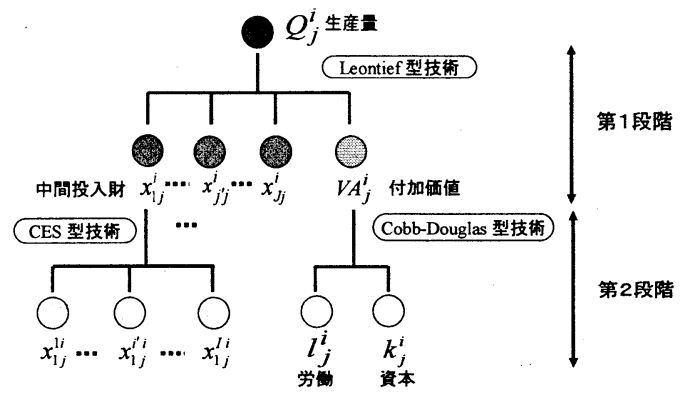

図-2 企業の行動モデル階層的構造

第 1 段階においては中間投入財と付加価値の生産技術 を Leontief 型で仮定し, 地域 $i$ の $j$ 財を生産する企業の 生産関数を以下のように定式化する.

$$
Q_{j}^{i}=\min \left(\frac{V A_{j}^{i}\left(l_{j}^{i}, k_{j}^{i}\right)}{a_{0 j}^{i}}, \frac{x_{1 j}^{i}}{a_{1 j}^{i}}, \cdots, \frac{x_{j^{\prime} j}^{i}}{a_{j^{\prime} j}^{i}}, \cdots, \frac{x_{J_{j}}^{i}}{a_{J_{j}}^{i}}\right)
$$

ただし, $Q_{j}^{i}$ :地域 $i$ 産業 $j$ の生産量, $V A_{j}^{i}$ : 地域 $i$ 産業 $j$ の 付加価值, $x_{j^{\prime} j}^{i}$ :地域 $i$ の産業 $j^{\prime}$ から産業 $j$ への中間投入 合成財, $a_{j^{\prime} j}^{i}$ :地域 $i$ の産業 $j^{\prime}$ から産業 $j$ への中間投入合 成財の投入係数, $a_{0 j}^{i}$ : 地域 $i$ 産業 $j$ の付加価值比率

第 2 段階における付加価値は, 労働と資本について規 模に関して収穫一定である Cobb-Douglas型を仮定する.

$$
\begin{aligned}
& \min w^{i} l_{j}^{i}+r^{i} k_{j}^{i} \\
& \text { s.t. } V A_{j}^{i}=\eta_{j}^{i} l_{j}^{i \alpha_{1 j}^{i}} k_{j}^{i \alpha_{2 j}^{\prime}}
\end{aligned}
$$

ただし, $w^{i}$ :地域 $i$ の労働賃金率, $r^{i}$ : 地域 $i$ の資本レント, $l_{j}^{i}$ : 地域 $i$ 産業 $j$ の労働投入量, $k_{j}^{i}$ : 地域 $i$ 産業 $j$ の資本投 入量, $\eta_{j}^{i}$ :地域 $i$ 産業 $j$ の効率パラメータ, $\alpha_{1 j}^{i}$ :地域 $i$ 産 業 $j$ の生産要素(労㗢)の分配パラメータ, $\alpha_{2 j}^{i}$ 地域 $i$ 産業 $j$ の生産要素(労働)の分配パラメータ $\left(\alpha_{1 j}{ }^{i}+\alpha_{2 j}{ }^{i}=1\right)$
式(2)よりラグランジュ未定乗数法により解くと付加価 值 1 単位あたり生産要素需要関数が求まる.

$$
\begin{aligned}
& \text { (労働) } \quad c l_{j}^{i}=\left(\eta_{j}^{i}\right)^{-1}\left(\frac{\alpha_{1 j}^{i} r^{i}}{\alpha_{2 j}^{i} w^{i}}\right)^{\alpha_{2 j}^{\prime}} \\
& \text { (資本) } \quad c k_{j}^{i}=\left(\eta_{j}^{i}\right)^{-1}\left(\frac{\alpha_{2 j}^{i} w^{i}}{\alpha_{1 j}^{i} r^{i}}\right)^{\alpha_{1 j}^{i}}
\end{aligned}
$$

また，第 2 段階における企業の中間投入合成財に関し ては, 地域内外の生産技術を CES 型で仮定し, 各地域か らの中間投入財の投入制約下の費用最小化行動として以 下のように定式化を行う.

$$
\begin{aligned}
& \min \sum_{i \in I} P_{j^{\prime}}^{i^{i}} x_{j^{i} j}^{i^{i}} \quad\left(=\sum_{i \in I}\left(1+t^{i^{i}}\right) P_{j^{\prime}}^{i^{\prime}} x^{i^{\prime i} j}\right) \\
& \text { s.t. } x_{j^{j} j}^{i}=\phi_{j j}^{i}\left(\sum_{i \in I} \delta_{j^{\prime} j}^{i^{i}} x_{j^{\prime} j}^{i^{i} \frac{\sigma-1}{\sigma}}\right)^{\frac{\sigma}{\sigma-1}}=1
\end{aligned}
$$

ただし， $P_{j^{\prime}}^{i^{\prime}}$ : 地域 $i^{\prime}$ で生産された産業 $j^{\prime}$ の財を地域 $i$ で消費する際の価格 $\left(P_{j^{\prime}}^{i^{\prime} i}=\left(1+t^{i}\right) P_{j^{\prime}}^{i^{\prime}}\right), x_{j^{\prime} j}^{i^{i} i}$ 地域 $i^{\prime}$ から 地域 $i$, 産業 $j^{\prime}$ から産業 $j$ への中間投入財, $\phi_{j^{\prime} j}^{i}$ : 地域 $i$ の 産業 $j^{\prime}$ から産業 $j$ への効率パラメータ, $\delta_{j^{\prime} j}^{i^{\prime} j}$ :地域 $i^{\prime}$ から 地域 $i$, 産業 $j^{\prime}$ から産業 $j$ への分配パラメータ $\left(\sum_{i \in I} \delta_{j^{\prime} j}^{i^{\prime}}=1\right), \sigma$ :企業の地域選択の代替弾力性, $t^{i^{i}}$ :生産 地価格と消費地価格のギャップ

式(5)をラグランジュ未定乗数法により解くと中間投入 合成財 1 単位あたりの中間投入需要関数が求まる.

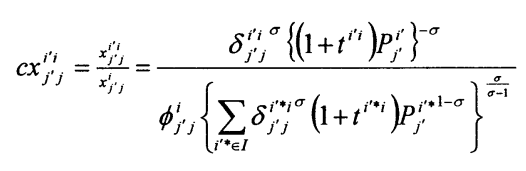

また, この最適化問題に付随するラグランジュ乗数より， 合成財価格 $P_{j^{\prime} j}^{i}$ が決定される.

$$
P_{j^{\prime} j}^{i}=\left(\phi_{j^{\prime} j}^{i}\right)^{-1}\left(\sum_{i^{\prime} \in I} \delta_{j^{\prime} j}^{i^{\prime} \sigma}\left(1+t^{i^{\prime i}}\right) P_{j^{\prime}}^{i^{\prime-\sigma}}\right)^{\frac{1}{1-\sigma}}
$$

さらに, 企業の生産関数が規模に関して収穫一定を仮 定しているため企業の超過利潤はゼロとなり, かつ価格 受容者である企業が直面する生産財価格は単位生産量あ たりの生産費用(平均費用)に等しくなる.

$$
\begin{aligned}
P_{j}^{i} & =\frac{\left(w^{i} l_{j}^{i}+r^{i} k_{j}^{i}\right)+\sum_{j^{\prime} \in J} P_{j^{\prime} j}^{i} x_{j^{\prime} j}^{i}}{Q_{j}^{i}} \\
= & a_{0 j}^{i}\left(w^{i} c l_{j}^{i}+r^{i} c k_{j}^{i}\right)+\sum_{j^{\prime} \in J} a_{j^{\prime} j}^{i} P_{j^{\prime} j}^{i}
\end{aligned}
$$




$$
\begin{aligned}
= & a_{0 j}^{i}\left(w^{i} c l_{j}^{i}+r^{i} c k_{j}^{i}\right) \\
& +\sum_{j^{\prime} \in J} a_{j^{\prime} j}^{i}\left(\phi_{j^{\prime} j}^{i}\right)^{-1}\left(\sum_{i^{\prime} \in I} \delta_{j^{\prime} j}^{i^{i} \sigma}\left(1+t^{i^{i} i}\right) P_{j^{\prime}}^{i^{\prime} 1-\sigma}\right)^{\frac{1}{1-\sigma}}
\end{aligned}
$$

（3）世帯の行動モデル

各地域には代表的世帯が存在し, 図-3に示すようなネス ティッド CES 型の効用関数構造を持つと仮定する.

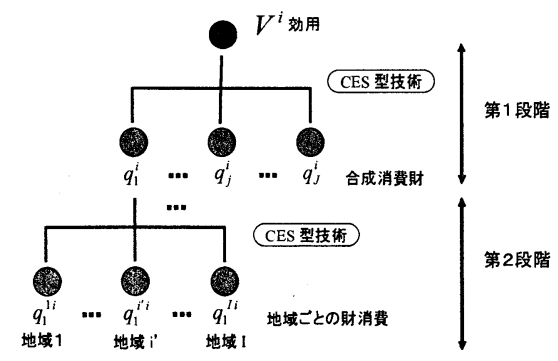

図-3 世帯の行動モデル階層的構造

第1段階では各合成消費財の代替関係を CES 型で表現 し, 所得制約条件下での効用最大化行動として以下のよ うに定式化する.

$$
\begin{aligned}
& V^{i}=\max \left(\sum_{j \in J}\left(\gamma_{j}^{i}\right)^{\frac{1}{\rho 1}}\left(q_{j}^{i}\right)^{\frac{\rho-1-1}{\rho 1}}\right)^{\frac{\rho 1}{\rho l-1}} \\
& \text { s.t. } \sum_{j \in J} p_{j}^{i} q_{j}^{i}=w^{i} L^{i}+r^{i} K^{i}
\end{aligned}
$$

ただし, $V^{i}$ :地域 $i$ の間接効用関数, $q_{j}^{i}$ :地域 $i$ の世帯が消 費する産業 $j$ の合成財消費量, $L^{i}$ : 地域 $i$ の労働供給量, $K^{i}$ : 地域 $i$ の資本供給量, $\gamma_{j}^{i}$ :地域 $i$ の世帯における産業 $j$ からの消費分配パラメータ， $\rho_{1}$ :世帯の合成消費における 財選択の代替弾力性, $p_{j}^{i}$ 地域 $i$ の世帯が直面する産業 $j$ の合成消費財価格

式(9)を解くと合成消費財の需要関数が得られる.

$$
q_{j}^{i}=\frac{\gamma_{j}^{i}\left(w^{i} L^{i}+r^{i} K^{i}\right)}{\left(p_{j}^{i}\right)^{\rho} \sum_{j \in J}\left(p_{j}^{i}\right)^{1-\rho} \gamma_{j}^{i}}
$$

次に第 2 段階では, 合成消費財を形成する自地域製品 と他地域製品の代替関係を CES 型で表現する. 合成消費 財需要関数から財の生産地別の消費水淮を求めるために, 合成消費財消費制約下でのサブ効用最大化行動として定 式化する.

$$
\begin{aligned}
& V_{j}^{\prime i}=\max \left(\sum_{i^{i} \in I}\left(\gamma_{j}^{i i}\right)^{\frac{1}{\rho_{2}}}\left(q_{j}^{i i}\right)^{\frac{\rho_{2}-1}{\rho_{2}}}\right)^{\frac{\rho_{2}}{\rho_{2}-1}} \\
& \text { s.t. } p_{j}^{i} q_{j}^{i}=\sum_{i^{\prime} \in I} P_{j}^{i^{i} i} q_{j}^{i^{i i}} \quad\left(=\sum_{i^{\prime} \in I}\left(1+t^{i_{i}}\right) P_{j}^{i^{i}} q_{j}^{i^{i} i}\right)
\end{aligned}
$$

ただし, $V^{\prime}{ }_{j}$ :地域 $i$ における産業 $j$ の財に関する効用関 数, $q_{j}^{i^{\prime} i}$ : 地域 $i$ の世帯が消費する地域 $i^{\prime}$ 産業 $j$ の合成財消
費量, $\gamma_{j}^{i^{i} i}$ : 地域 $i^{\prime}$ から地域 $i へ の$ 産業 $j$ の消費分配パラメ 一夕, $\rho_{2}$ :世帯の合成消費財における地域選択の代替弾力 性

式(11)より, 地域ごとの合成消費財の消費水準 $c q_{j}^{i i}$ が求 まる.

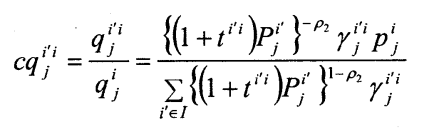

さらに, 合成消費財の価格は式(11)の最適化条件に付随 するラグランジュ乗数の逆数として求められる.

$$
p_{j}^{i}=\left[\sum_{i^{\prime} \in I} \gamma_{j}^{i_{j}^{i}}\left(1+t^{i^{i}}\right) P_{j}^{i^{\prime}}\left(1-\rho_{2}\right)\right]^{\frac{1}{1-\rho_{2}}}
$$

\section{（4）均衡条件}

本モデルは企業に対して規模に関して収穫一定の生産 技術を仮定しており, 企業は常に需要に応じた生産を行 う. そのため生産財市場における市場均衡条件は常に成 立し, 財価格は単位生産量あたりの費用として決定され る. つまり式(8)で表現される $i \times j$ 個の方程式を解くこと で財価格を求めることができる. そこで, 本モデルの均 衡条件としては財価格の均衡条件に加えて, 本源的生産 要素市場である労働市場と資本市場の均衡条件を考慮し， 世帯の生産要素供給量と企業の生産要素需要量が一致す ると考える. 以下に均衡条件式を示す.

生産財市場

$$
Q_{j^{\prime}}^{i}=\sum_{i \in I} \sum_{j \in J}\left(1+t^{i i}\right) x_{j j}^{i i}+\sum_{i \in I}\left(1+t^{i i}\right) c q_{j^{\prime}}^{i i} q_{j^{\prime}}^{i}
$$

生産財価格体系

$$
\begin{aligned}
P_{j}^{i}= & a_{0 j}^{i}\left(w^{i} c l_{j}^{i}+r^{i} c k_{j}^{i}\right) \\
& \left.+\sum_{j^{\prime} \in J} a_{j^{\prime} j}^{i}\left(\phi_{j^{\prime} j}^{i}\right)^{-1}\left(\sum_{i^{\prime} \in I} \delta_{j^{\prime} j}^{i^{i} \sigma}\left(1+t^{i^{i} i}\right) P_{j}^{i^{1}}\right)^{1-\sigma}\right)^{\frac{1}{1-\sigma}}
\end{aligned}
$$

生産要素市場

$$
\begin{array}{ll}
\text { (労働) } & \sum_{j \in J} a_{1 j}^{i} \frac{a_{0 j}^{i} Q_{j}^{i}}{w^{i}}=L^{i} \\
\text { (資本) } & \sum_{j \in J} a_{2 j}^{i} \frac{a_{0 j}^{i} Q_{j}^{i}}{r^{i}}=K^{i}
\end{array}
$$

\section{（5）便益の定義}

本モデルにおいて, 企業の生産に必要な本源的生産要 素は世帯から供給される労衝と資本であるため, 道路整 備による効果は企業を通じて最終的には，世帯に帰着す ることになる.そこで道路整備前後の世帯の効用水淮変化 を用いて等価変分(EV: Equivalent Variation)によって定義 
する.

$$
\begin{aligned}
E V & =e\left(q^{0}, V^{1}\right)-e\left(q^{0}, V^{0}\right) \\
& =\left(w^{0} L+r^{0} K\right)\left[\frac{V^{1}-V^{0}}{V^{0}}\right] \\
& =I^{0}\left[\frac{V^{1}-V^{0}}{V^{0}}\right]
\end{aligned}
$$

ただし, 0,1 :道路整備前後を表すサフィックス, $I$ :可処 分所得, $e$ :支出関数

\section{（6）マークアップ率}

道路ネットワーク整備は地域間移動の所要時間短縮を もたらす，モデル中においてはマークアップ率（交通抵 抗） $t^{t^{i i}}$ の減少で表現することが可能である. マークアッ プ率の導出方法は, 道路整備前の交通一般化費用を算出 して，その変化率に対して財価格に占める交通費用の割 合を乗じて求めている. なお本検討において, 東アジア 経済シナリオは, 地域間所要時間短縮インパクトの変化 に伴って, このマークアップ率が変化するとして考慮し ている. 詳細なシナリオのモデル化の手法については, 3.において説明を行う.

$$
\begin{aligned}
& t^{i_{i}}=\frac{C^{i^{i}}{ }_{1}-C^{i^{i}{ }_{0}}}{C^{i^{i}{ }_{0}}} \times \beta \\
& C^{i i_{0}}=v \times T^{i i_{0}}+d^{i i_{0}} \\
& C^{i i_{1}}{ }_{1}=v \times T^{i{ }^{i}}{ }_{1}+d^{i{ }^{i}}{ }_{1}
\end{aligned}
$$

ただし， $t^{i i}$ :マークアップ率， $\beta$ :財価格に占める輸送費 用の割合(一定), $v$ :時間価値(円/分), $T^{i^{i} i}$ : 所要時間, $d^{i^{i} i}$ : 所要費用(高速道路料金など), 0,1 : 道路整備後を表すサフ イックス

\section{3. 将来社会経斎シナリオのモデル化}

本研究では以下に示す case 0 から case 2 までの $3 つ$ の将来社会経済シナリオを想定する. 人口減少シナリ オでは, 生産年齢人口の減少を, モデル中の世帯が保 有する生産要素が減少することであるとして，考慮し ている. また，東アジア経済成長シナリオでは，東ア ジアの経済成長に伴う，日本と東アジア諸国との交易 拡大により, 国内の交通混雑が引き起こされると仮定 し，道路整備を行うことによって，混雑を改善する所 要時間短縮インパクトを考慮している. 各々のシナリ オの定量的分析へのモデル化の詳細については, 次節 以降に説明を行う.

・ case0:将来において現在と比べて変化なしとする

- case1:人口減少を考慮する

・ case2:人口減少と東アジア経済成長を考慮する

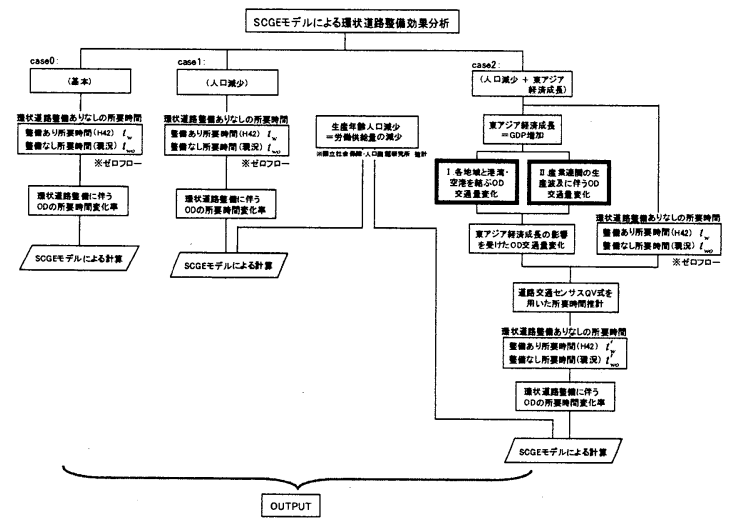

図-4 シナリオケース別分析フロー

\section{（1）人口減少シナリオ}

人口減少に伴う生産力減少のシナリオを分析に反映さ せる際は，生産年齢人口の減少を世帯の保有する本源的 生産要素である労働供給量の減少と捉え, 減少した労働 供給量をインプットデータとして用いる. 労働供給量が 減少した際に成り立つ均衡状態を without, 労働供給が 減少し,さらに, 所要時間短縮インパクトがもたらされ た状況下で成り立つ均衡状態を with と想定し, 人口減少

\begin{tabular}{|c|c|c|c|c|c|c|c|c|c|}
\hline & \multicolumn{2}{|c|}{$\begin{array}{c}\text { 生産力人口 } \\
\text { (蕇位: } 1,000 \text { 人) }\end{array}$} & \multirow{2}{*}{$\begin{array}{l}\text { 変化率 } \\
(\%)\end{array}$} & & & \multicolumn{2}{|c|}{$\begin{array}{c}\text { 生産力人口 } \\
\text { (单位: } 1,000 \text { 人) }\end{array}$} & \multirow{2}{*}{$\begin{array}{l}\text { 変化率 } \\
(\%)\end{array}$} \\
\hline & & $\begin{array}{l}\text { 平成7年 } \\
\text { (1995) } \\
\end{array}$ & $\begin{array}{c}\text { 平成 } 42 \text { 年 } \\
(2030)\end{array}$ & & & & \begin{tabular}{l|} 
平成7年 \\
(1995)
\end{tabular} & $\begin{array}{c}\text { 平成42年 } \\
(2030)\end{array}$ & \\
\hline 1 & 北海道 & 3,943 & 2,683 & $-32 \%$ & 25 & 洋賀累 & 874 & 950 & $9 \%$ \\
\hline 2 & 青森県 & 991 & 705 & $-29 \%$ & 26 & 京都府 & 1,842 & 1,460 & $-21 \%$ \\
\hline 3 & 岩手県 & 925 & 688 & $-26 \%$ & 27 & 大阪府 & 6,422 & 4,652 & $-28 \%$ \\
\hline 4 & 宮城県 & 1,596 & 1,383 & $-13 \%$ & \begin{tabular}{|l|}
28 \\
\end{tabular} & 兵庫県 & 3.756 & 3,199 & $-15 \%$ \\
\hline 5 & 秋田県 & 787 & 487 & $-38 \%$ & \begin{tabular}{|l|}
29 \\
\end{tabular} & 奈良県 & 999 & 767 & $\frac{1}{-23 \%}$ \\
\hline 6 & 山形显 & 799 & 571 & $-29 \%$ & 30 & 和歌山県 & 709 & 487 & $-31 \%$ \\
\hline 7 & 福悤県 & 1,380 & 1,047 & $-24 \%$ & \begin{tabular}{|l|}
31 \\
\end{tabular} & 鳥取県 & 391 & 307 & $-21 \%$ \\
\hline 8 & 茨城県 & 2,030 & 1,601 & $-21 \%$ & 32 & 島根県 & 478 & 346 & $-28 \%$ \\
\hline 9 & 厉木県 & 1,351 & 1,100 & $-19 \%$ & 33 & 岡山県 & 1,294 & 1.007 & $-22 \%$ \\
\hline 10 & 群馬県 & 1,360 & 1.058 & $-22 x$ & 34 & 広島県 & 1,956 & 1,454 & $-26 \%$ \\
\hline 11 & 埼玉県 & 4,977 & 4,167 & $-16 \%$ & \begin{tabular}{|l|}
35 \\
\end{tabular} & 山口県 & 1,019 & 665 & $-35 \%$ \\
\hline 12 & 千葉県 & 4,225 & 3.402 & $-19 \%$ & 36 & 德悤㛝 & 542 & 389 & $-28 \%$ \\
\hline 13 & 宩京都 & 8,705 & 7,792 & $-10 \%$ & \begin{tabular}{|l|}
37 \\
\end{tabular} & 香川県 & 678 & 496 & $-27 \%$ \\
\hline 14 & 神奈川県 & 6,098 & 5,348 & $-12 \%$ & 38 & 愛媛莀 & 982 & 692 & $-30 \%$ \\
\hline 15 & 新渴県 & 1.626 & 1,189 & $-27 \%$ & 39 & 高知県 & 522 & 391 & $-25 \%$ \\
\hline 16 & 富山県 & 752 & 542 & $-28 \%$ & 40 & 福岡県 & \begin{tabular}{|l|}
3,382 \\
\end{tabular} & 2.987 & $-12 \%$ \\
\hline 17 & 石川県 & 799 & 585 & $-27 \%$ & 41 & 佐賀県 & 567 & 420 & $-26 \%$ \\
\hline 18 & 福井莀 & 540 & 413 & $-24 \%$ & 42 & 長崎県 & 994 & 646 & $-35 \%$ \\
\hline 19 & 山梨畏 & 585 & 462 & $-21 \%$ & 43 & 態本贯 & 1,196 & 933 & $-22 \%$ \\
\hline 20 & 長野悬 & 1,421 & 1,149 & $-19 \%$ & 44 & 大分県 & 801 & \begin{tabular}{l|l}
558 \\
\end{tabular} & $-30 \%$ \\
\hline 21 & 岐阜紧 & 1.430 & 1,056 & $-26 \%$ & 45 & 宮崎県 & 761 & 550 & $-28 \%$ \\
\hline 22 & 解岡県 & 2,564 & 1,909 & $-26 \%$ & 46 & 鹿児悤県 & 1,120 & 895 & $-20 \%$ \\
\hline 23 & 受知県 & 4,919 & 4,182 & $-15 \%$ & 47 & 沖縺舆 & 842 & 843 & $0 \%$ \\
\hline 24 & 三重県 & 1,240 & 960 & $-23 \%$ & 48 & 全国 & 87,165 & 69,576 & $-20 \%$ \\
\hline
\end{tabular}
シナリオ下における所要時間短縮効果を推計する. なお, 本シナリオでは, 人口減少に伴う一般交通量低下から引 き起こされる所要時間短縮インパクトの変化は考慮して いない.

表-1 将来の生産年齢人口 4

（2）東アジア経済成長シナリオ

東アジアの経済成長は, 1995 年(平成 7 年)から 2030 年(平成 42 年)の間における中国の $\mathrm{GDP}^{习}$ の予測值をもつ て説明する．中国の経済成長に起因する日本と中国との 交易拡大に伴う交通量増加の要因として下記の 2 つの影 響を考慮する必要あると考える. 


\section{I. 各地域と港湾·空港を結ぶ OD 交通量変化}

II.産業連関の生産波及に伴う OD 交通量变化

I .に関しては交通トリップ増加による渋滞発生を想定 し，I.に関しては日本に対する追加的需要に関連する産 業活動に付随した交通トリップ増加を想定している.こ れら交通トリップ増加を反映した交通量のもとでの道路 整備ありなしの所要時間変化率を推計し，これらの変化 率をマークアップ率の変化としてモデルにインプットし ている. 交通トリップ増加により, without 時において は，現状よりも交通負荷が高い状況にあり，この東アジ ア経済成長シナリオを考慮した道路整備による所要時間 短縮インパクトは, 将来シナリオを考慮しない状況より も大きなものになると想定される，以下に，東アジア経 済成長シナリオを受けた OD 交通量推計方法について記 述を行う.

（a)各地域と港湾·空港を結ぶ OD 交通量変化

国内各地域がアジア向け輸出に利用する港湾·空港の 取り扱いデータ日を用いて, 現況における各地域と港湾. 空港を結ぶ交易量(重量ベース)を把握する. 輸出重量べー スの交易量を，下記の換算值をもとに 1 個の $20 \mathrm{ft}$ コンテ ナを 1 台のトラックであると仮定しトラック台数に換算 する.

\section{表-2 コンテナ換算値 ${ }^{n}$}

\begin{tabular}{|c|c|}
\hline コンテナタイプ(l) & 㷛物量 \\
\hline 20ftコンテナ & 18.7 フレートトン \\
\hline
\end{tabular}

次に中国の GDP を説明変数, 日本の輸出貨物トン量を 被説明変数として回帰分析を行い, 2030 年(H42 年)時点 の中国 GDP 推定値をもとに, 将来時点の日本の輸出貨物 トン量を推計する. 推計結果及び回帰分析に用いたデー 夕は以下の通りである. ただし, 本検討においては, 単 純化のために線形関数で定義している.

\section{表-3 中国 $G D P^{81}$ と日本の輸出貨物トン量 ${ }^{9}$}

\begin{tabular}{|c|c|c|c|c|}
\hline 年次 & 和底 & $\begin{array}{c}\text { 中国 GDP } \\
(1 \bar{\tau})\end{array}$ & $\begin{array}{c}a+x o+14 \\
y\left(x^{r}\right)\end{array}$ & $\begin{array}{l}\text { 推計輸出貨 } \\
\text { 物量 (千²) }\end{array}$ \\
\hline 1988 & S63 & 13,853 & 81,368 & 85,091 \\
\hline 1989 & $\mathrm{H} 01$ & 15,677 & 81,811 & 86,350 \\
\hline 1990 & $\mathrm{H} 02$ & 17,400 & 85,062 & 87,540 \\
\hline 1991 & $\mathrm{HO}$ & 19,580 & 90,580 & 89,045 \\
\hline 1992 & $\mathrm{H} 04$ & 23,938 & 100,728 & 92,055 \\
\hline 1993 & $\mathrm{H} 05$ & 31,380 & 108,177 & 97,194 \\
\hline 1994 & $\mathrm{H} 06$ & 43,800 & 111,981 & 105,770 \\
\hline 1995 & $\mathrm{H} 07$ & 57,733 & 116,636 & 115,391 \\
\hline 1996 & $\mathrm{H} 08$ & 67,795 & 115,703 & 122,339 \\
\hline 1997 & $\mathrm{H} 09$ & 74,772 & 120,419 & 127,157 \\
\hline 1998 & $\mathrm{H} 10$ & 79,553 & 119,325 & 130,459 \\
\hline 1999 & $\mathrm{H} 11$ & 82,054 & 125,840 & 132,186 \\
\hline 2000 & $\mathrm{H} 12$ & 89,404 & 131,482 & 137,261 \\
\hline 2001 & $\mathrm{H} 13$ & 95,933 & 139,332 & 141,769 \\
\hline 2002 & $\mathrm{H} 14$ & 102,398 & 155,062 & 146,234 \\
\hline 2003 & $\mathrm{H} 15$ & 117,252 & 168,825 & 156,491 \\
\hline 2030 & $\mathrm{H} 42$ & $1,179,466$ & & 889,982 \\
\hline
\end{tabular}

$$
Y=0.69053 X+75524.8
$$

ただし, $Y$ :日本の輸出貨物トン量(千トン), $X$ :中国 GDP(億元)

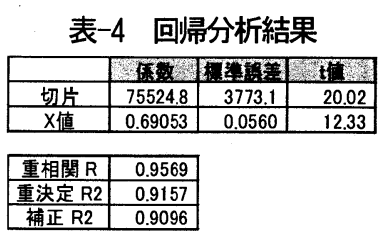

中国の GDP成長率は約1,943\%(1995-2030年)であり, 金額にして 1,179,466 億元にのぼると想定される. 推定 した回帰式を用いると, 2030 年時点で日本の輸出貨物卜 ン量は 889,982 千トン, 2003 年と比較すると約 5.7 倍の 規模に膨らむここが想定される.ここで，日本の輸出貨 物トン量の増加率と同じ率で都道府県別アジア向け輸出 重量が増加すると仮定を置き，東アジア経済成長による 各都道府県と港湾.空港を結ぶ OD 交通量変化率の推計 を行う.

(b)産業連関の生産波及に伴う OD 交通量変化

まず中国と日本の貿易状況を把握するためにアジア国際 産業連関表 ${ }^{10)}$ より日本から中国への輸出額の集計を行い, 中国のGDP成長率を考慮して 2030 年(平成 42 年)の将来時 点における中国向けの輸出増咖額を算出する(表-5).

表-5 中国に対する輸出額 ${ }^{10}$

\begin{tabular}{|c|c|c|c|c|}
\hline & & atop & (2) & $\begin{array}{c}\text { 中国向け輸出額 } \\
\text { 增加分: } 2030 \text { 年 } \\
\text { (1) } \times 1.943 \%) \\
\end{array}$ \\
\hline 1 & 農業、林業、漁業、畜産 & 48,609 & 67 & 1,301 \\
\hline 2 & 鉱業、採石業 & 40 & 18 & 348 \\
\hline 3 & 製造業 & $1,342,538$ & 26,113 & 507,360 \\
\hline 4 & 電気・ガス・水道業 & 74,970 & 0 & 0 \\
\hline 5 & 建設業 & 844,151 & 0 & 0 \\
\hline 6 & 商業、運輸業 & 851,171 & 2,859 & 55,549 \\
\hline \multirow[t]{2}{*}{7} & サービス業 & $2,155,428$ & 3 & 61 \\
\hline & 合計 & $5,316,906$ & 29,060 & 564,619 \\
\hline
\end{tabular}

1995 年時点における日本の中国向け輸出額である約 291 億ドルに中国の GDP成長率(1943\%)を乗じて算出し た約 5,600 億ドルが追加的需要として日本に帰着するも のと考える. 国内の各都道府県に対する帰着額について は, 中国向け海上・航空輸出金額の実績をもとに集計し た下表に示す割合を用いて算出する.

表-6 中国向け総榆出金額に占める各県の中国向け輸出金額の

\begin{tabular}{|c|c|c|c|c|c|c|c|c|c|}
\hline 部进有留名 & 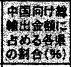 & 都道府果名 & 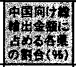 & 邦道府深名 & 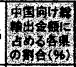 & 钣道府㬎名 & 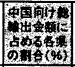 & 都道府果名 & 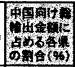 \\
\hline 北海道 & $0.4 \%$ & 埼五果 & $4.3 \%$ & 䝛阜渠 & $1.9 \%$ & 㞅 & $0.9 \%$ & 實黑 & $0.5 \%$ \\
\hline 骨视 & & & & & $3.1 \%$ & & & & 010 \\
\hline 岩到 & & & & & $8.2 \%$ & & & & $0.6 \%$ \\
\hline & $1.1 \%$ & 神奈州果 & $7.1 \%$ & & 2.0 & & & 大分果 & $1.3 \%$ \\
\hline & & & & & 2. & & 2.5 & & \\
\hline 山形果 & & & $1.0 \%$ & & $2.0 \%$ & & 0. & & 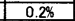 \\
\hline 楅 & & & & & 11.1 & & & 沖䋥県 & $0.0 \%$ \\
\hline & & & & & & & & 全国 & $100.0 \%$ \\
\hline & 1.4 & & 0.0 & & $0.1 \%$ & & $0.0 \%$ & & \\
\hline 群馬果 & $2.4 \%$ & 長䝑桨 & $4.1 \%$ & 和歌山果 & $0.7 \%$ & 福岡罯 & $2.2 \%$ & & \\
\hline
\end{tabular}


上記で推計した将来時点の最終需要額を産業連関表に 代入し，産業連関を通じた国内地域間の波及考慮し，産 業連関表の内生部門における交易量の変化率を OD 交通 量変化率と捉える.

これら a)，b)で推計された OD 交通量変化率を足しあ わせた変化率を現況の交通量配分結果の交通量に乗じて, 東アジア経済成長を受けた将来時点の OD 交通量を推計 する.

(c)QV 式を用いた混雑の表現

東アジア経済成長を受けた OD 交通量をもとに，道路 交通センサス ${ }^{111}$ で設定されている $\mathrm{QV}$ 式を用いて，道路 整備前後の所要時間変化率を算出する. ただし，本検討 においては, 地域の内々交通量の変化は対象にしておら ず，東アジア経済成長シナリオを受けた内々の所要時間 短縮インパクトの変化は考慮していない，

\section{前提条件}

・対象とする OD は, with-without で所要時間が減少し ている OD とする. すなわち, 大環状道路ネットワー クの整備効果のある OD を対象とする.

・増加を想定しない時の without 時の交通量は Qmin で 与えられ，下図のように交通量が増加することにより 速度が減少すると考える.

・単純化のために without 時の府県間のリンクは ODに 1 本と仮定し, 路線を特定する. 府県間の交通は, 全て この特定した路線を通るものとする.

・道路整備が完成する with 時は混雑が発生しないと仮定 する.

図-5 QV 式を用いた混雑の考え方

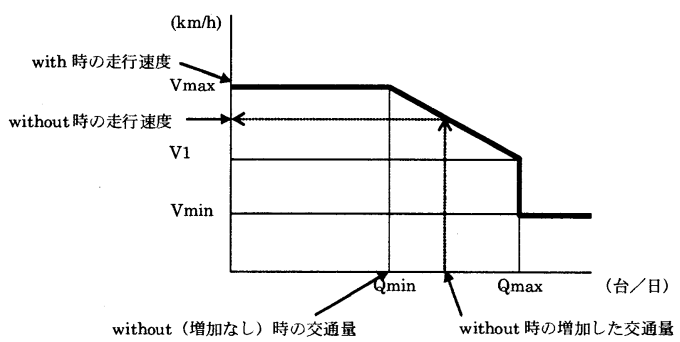

表-7 without 時の対象路線と QV 条件

\begin{tabular}{|c|c|c|c|c|c|c|c|}
\hline 程施 & 遗路 & 軍数 & $V_{\max }$ & $V_{1}$ & Vhin & Qmin & Omax \\
\hline 名神高速 & \multirow{4}{*}{$\begin{array}{c}\text { 高規格幹 } \\
\text { 線道路 }\end{array}$} & 4 & 100 & 50 & 10 & 0 & 64,000 \\
\hline 近畿自動車道紀勢線 & & 4 & 100 & 50 & 10 & 0 & 64,000 \\
\hline 中国自動車道 & & 4 & 100 & 50 & 10 & 0 & 48,000 \\
\hline 瀬戸大橋 & & 4 & 100 & 50 & 10 & 0 & 64,000 \\
\hline 国道24号 & \multirow{2}{*}{\begin{tabular}{|c} 
国道パイ \\
パス
\end{tabular}} & 4 & 60 & 30 & 10 & 25,000 & 50,000 \\
\hline 名阪国道 & & 4 & 60 & 30 & 10 & 25,000 & 50,000 \\
\hline
\end{tabular}

\section{4. パラメー夕設定}

本研究が対象とする地域区分は 47 都道府県とし, 産業 分類は下表に示すように 8 産業とする. また, 基準均衡 データとして都道府県間産業連関表 ${ }^{12}$ を用いる.

\begin{tabular}{|c|c|c|}
\hline & 表-8 & \\
\hline \begin{tabular}{l|l|l|}
1 & 農林水産業 \\
2
\end{tabular} & \begin{tabular}{|l|l|}
4 & 電気・ガス・水道業 \\
\end{tabular} & \begin{tabular}{|l|l|}
7 運輸·通信業 \\
\end{tabular} \\
\hline $\begin{array}{l}3 \\
3\end{array}$ & 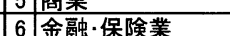 & \\
\hline
\end{tabular}

モデル内の各経済主体の行動モデルに関するパラメー 夕は前述の基準均衡デー夕を用いてキャリブレーション 手法によって導出した. ただし, 代替弾力性については 既存研究の值を採用した. パラメータの詳細については, 下表において示す.

表-9 企業行動に関するパラメータ

\begin{tabular}{|c|c|c|c|}
\hline \multicolumn{2}{|r|}{ パラメータ } & $\vec{\tau}$ 一夕説明(道出方法) & 出典 \\
\hline$a_{0 j}^{i}$ & 付加俩值比事 & $a_{0_{j}}^{i}=\frac{V A_{j}^{i}}{P_{j}^{i} Q_{j}^{i}}=\frac{w^{i} l_{j}^{i}+r^{i} k_{j}^{i}}{P_{j}^{i} Q_{j}^{i}}$ & 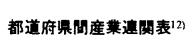 \\
\hline$a_{j^{\prime} j}^{i}$ & 投入係数 & $a_{j^{\prime} j}^{i}=\frac{x_{j j}^{i}}{P_{j}^{i} Q_{j}^{i}}$ & 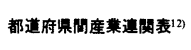 \\
\hline$\alpha_{1 j}^{i}$ & $\begin{array}{l}\text { 付加俩値の分配パラメー } \\
\text { 夕(労偟) }\end{array}$ & $\alpha_{1}^{i}=\frac{w^{i} l_{j}^{i}}{w^{\prime} l_{j}^{\prime}+r^{i} k_{j}^{\prime}}$ & 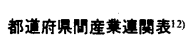 \\
\hline$\alpha_{2 j}^{\prime}$ & $\begin{array}{l}\text { 付加值值の分配パラメー } \\
\text { 夕(資本) }\end{array}$ & $a_{2 j}^{\prime}=\frac{r^{i} k_{j}^{i}}{w l_{j}^{\prime}+r^{\prime} k_{j}^{\prime}}=1-a_{1 j}^{\prime}$ & 都道府紧間産菜尰関表12) \\
\hline$\eta_{j}^{i}$ & $\begin{array}{l}\text { 付加俩値の効事パラメー } \\
\text { צ }\end{array}$ & $\eta_{j}=\frac{w^{i} l_{j}^{i}+r^{i} k_{j}^{i}}{\left\{l_{j}^{\alpha_{i}^{\prime},}\right\}\left\{k_{j}^{\alpha_{i}^{\prime}, j}\right\}}$ & 都道府県間産莱尰閣表'12) \\
\hline$\delta_{j j}^{i t}$ & $\begin{array}{l}\text { 中間投入の分配パラメー } \\
\text { 夕 }\end{array}$ & 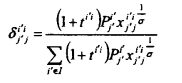 & 都道府紧咸産菜道関表 ${ }^{12}$ \\
\hline$\phi_{j^{\prime} j}^{i}$ & 中間投入の効率パラメー & 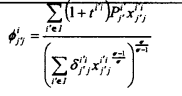 & 都道府紧間痤集尰閣表127 \\
\hline$\sigma$ & 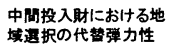 & 0.8 & 既存研究 ${ }^{13)}$ \\
\hline
\end{tabular}

表-10 世帯行動に関するパラメータ

\begin{tabular}{|c|c|c|c|}
\hline \multicolumn{2}{|r|}{ パラメータ } & デー夕説明(祥出方法) & 出典 \\
\hline$\gamma_{j}^{i}$ & $\begin{array}{c}\text { 分配パラメータ } \\
\text { (合成消費䀒に間する) }\end{array}$ & $\gamma_{j}^{i}=\frac{p_{j}^{\prime \rho_{i}} q_{j}^{\prime}}{\sum_{j \in J} p_{j}^{i{ }^{\prime \rho}} q_{j}^{i}}$ & 都道府県間産業遺阔表 ${ }^{122}$ \\
\hline$y_{j}^{i t}$ & $\begin{array}{c}\text { 分配パラメータ } \\
\text { (消費財に闌する) }\end{array}$ & $\gamma_{j}^{t_{i}}=\frac{q_{j}^{i_{i}^{i}}\left\{\left(1+t^{t^{i}}\right) P_{j}^{\prime}\right\}_{i}^{\rho_{z}}}{\sum_{i=1} q_{j}^{i_{i} i}\left\{\left(1+t^{i}\right) P_{j}^{\prime}\right\}^{p_{i}}}$ & 都道府県間座莱尰関表 ${ }^{12}$ \\
\hline$\rho_{3}$ & $\begin{array}{l}\text { 合成財消費の財逻択の } \\
\text { 代替弾力性 }\end{array}$ & 0.8 & 既存研究 ${ }^{14)}$ \\
\hline$\rho_{2}$ & $\begin{array}{l}\text { 合成財消費の地域買択 } \\
\text { の代然弹力性 }\end{array}$ & 0.8 & 既存研究 ${ }^{131}$ \\
\hline
\end{tabular}

\section{5. 実証分析}

実証分析として，第二名神，京奈和自動車道，神戸淡 路鳴門自動車道, 山陽自動車道, 紀淡連絡道路の 5 路線 から構成される関西大環状道路の整備効果について将来 の社会経済シナリオを組み込んで計測を行った. まず, 具体的な道路ネットワーク条件としては, 関西大環状道 路において既に供用されている区間であっても without のネットワークに含めず，環状道路リング全体の効果を 把握することに焦点をあてた設定とした. 将来社会経済 
シナリオについては 3.で説明した case 0 から case2 まで の 3 ケースを取り扱う. 以下に 3 つの将来シナリオ, 分 析対象路線図を示す.

• case0:将来において現在と比べて変化なし(基本)

・ case1:人口減少を考慮した場合(人口減少)

・ case2:人口減少と東アジア経済成長を考慮した場合(人 口減少十東アジア経済成長)

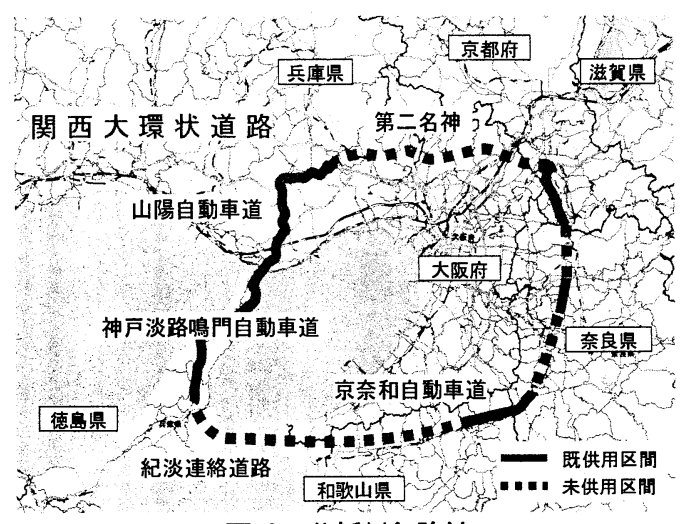

図-6 分析対象路線

図-7 はシナリオケース毎の生産額(産業合計)の変化額 を表している. case1の下での変化額は, case0 の結果を 下回っているが, 生産額は増加している. 人口減少社会 において, 道路整備が生産額減少に歯止めをかける効果 が表れていると考えることができる.

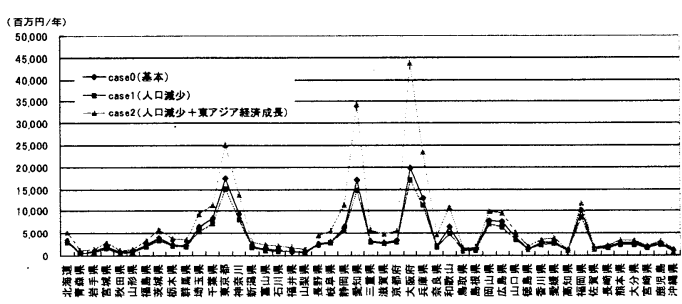

図-7シナリオケース別生産額変化 (産業合計)

また，図-8 は単年度あたりの便益をプロットしたもの であるが，生産額変化と同様の傾向を示している，便益 の全国合計では case0:約 3,145 億円/年, case1:約 2,722 億円となった. 一方, case2では, 交易拡大に伴う地域間 OD 交通量増加による without 時の走行速度低下を想定 しているため，交通トリップの集中が予想される貿易拠 点となる港湾·空港を有する地域及び背後圈となる地域 において, case1 と case2 の便益の差が非常に大きくなつ ている. case2 における便益の全国合計は約 3,958 億円/ 年であった.

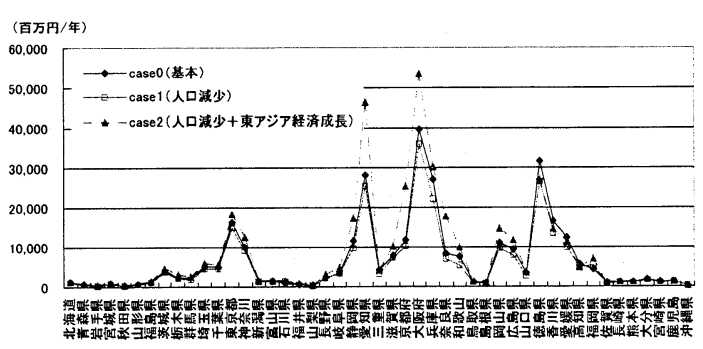

図-8シナリオケース別単年度便益

図-9 は case 0 における便益について都道府県別に塗り 分けたものである. case0 から case2 までの結果は便益の 大きさは各々異なるものの, 各都道府県に対する便益の 波及状況には大きな違いはみられず, 関西大環状道路の リング全体の効果は近畿だけでなく, 全国的に波及して いる. 特に地域間移動の所要時間短縮が大きな地域及び 首都圏, 中部圈など既存の産業·経済の集積地において便 益が大きいことが確認できる.

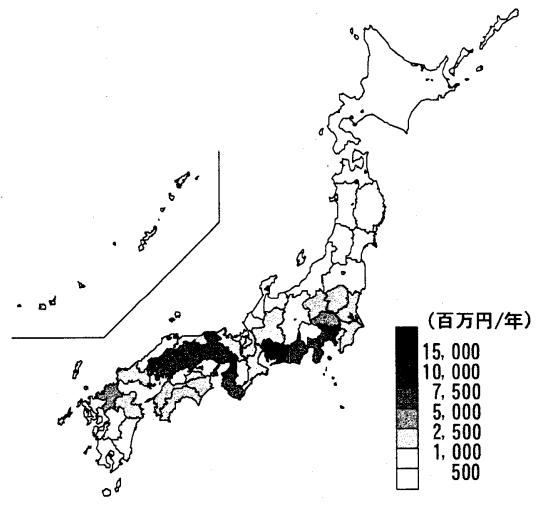

図-9 case 0 における単年度便益

\section{6. おわりに}

本研究では, 従来型の SCGE 分析による便益計測に加 えて，将来社会経済シナリオを考慮した場合の便益の計 測手法および実証分析結果を示した.ここで扱った将来 社会経済シナリオは(1)人口減少シナリオ(2)東アジア地域 の経済成長シナリオである。これらの将来社会経済シナ リオを, 経済理論と整合的な CGE のフレームの中で考慮 し，同じ土俵の上で表現することを試みた，その結果か らは, 将来経済シナリオの考慮により, 便益総額（総社 会的便益）への影響はもとより，その地域間分配（地域 帰着便益）に大きく影響することがわかった. なお，本 研究での(2)東アジア地域の経済成長シナリオに関しては, かなり限定的な分析となっている. そのため, より詳細 な結果を算出するためには以下の改良を加える必要があ る. (1)輸出入量の増加による交通混雑を県間の QV 式を 用いて推定しているが，交通ネットワーク配分モデルを 
用いた分析をする必要がある. (2)輸出入量の変化は，本 来ならば国内生産財市場の純輸出項目として, その影響 を考慮すべきである．以上の改良を考慮することでより 精度の高いシナリオを設定することができ，シナリオに 応じて精緻な分析が可能となる.

\section{謝辞}

本研究を遂行するにあたり, 三菱UFJリサーチ\&コンサ ルティング加藤義人氏に貴重なご示唆を頂いた.ここに 記して感謝の意を示す. なお，本稿に関するあらゆる誤 りや責任は筆者に帰属するものである.

\section{参考文献}

1) 土木学会土木計画学研究委員会:応用一般均衡モデ ルの公共投資評価への適応,土木学会ワンデイセミナ 一,シリーズ 15,1998.

2) 小池淳司:応用一般均衡分析における政策変数設定, 第 57 回土木学会中国支部研究発表会発表概要 集,pp.325-326,2005.

3) Nordhaus, D. W. and J. Boyer : Roll the DICE Again, MIT Press, 1999.

4) 国立社会保障·人口問題研究所:都道府県の将来推計 人口,2002.
5) Goldman Sachs, Dreaming With Brics : The Path to 2050, Global Economics Paper No.99,2003.

6) 財務省関税局調査保税課評価倸(輸出入貨物物流動 向研究会):輸出入貨物に係る物流動向調査(平成 15 年 4 月), 日本関税協会, 2003.

7) 港湾投資の社会経済効果に関する調査委員会:港湾 投資の評価に関するガイドライン 1999,pp.2-2-37, 1999.

8）中国情報局 http://searchina.ne.jp

9）(財)日本関税協会:外国貿易概況.

10) アジア経済研究所:1995 年アジア国際産業連関表, 2001.

11）国土交通省道路局:平成 11 年度道路交通センサス, (社)交通工学研究会,2001.

12）宮城俊彦·石川良文·由利昌平·土谷和之:地域内産 業連関表を用いた都道府県間産業連関表の作成,土 木計画学研究·論文集,Vol.20.No.1,pp.87-95,2003.

13）小池淳司・上田孝行・秋吉盛司:社会資本ストック 崩壊による経済的被害の空間的把握一空間的応用 一般均衡モデルによる計量厚生分析一, 土木計画学 研究論文集, Vol.21,no.2,pp.367 - 374,2004.

14）市岡修:応用一般均衡分析,有斐閣,1991.

\section{将来社会経斎シナリオ下でのSCGE モデルによる道路投資評価*}

小池淳司** 右近崇*** ・ 宮下光宏**** ・ 佐藤尚 $* * * * *$

近年，ワルラス体系を忠実に再現した応用一般均衡分析（以下，CGE 分析）は，交通整備事業に代表される 社会基盤計画の評価手法として広く用いられてきている. そこで本研究では，将来の社会経済変化を経済理論 と整合的に考慮することが可能であるという CGE 分析の特徵を生かし, 将来における人口減少および東アジ ア地域の経済成長を対象といった将来の社会経済環境変化（以下，将来社会経済シナリオ）を考慮した道路投 資の便益評価の感度分析を行うことを目的としている. 具体的には, 従来の空間的一般均衡モデルにこれら将 来社会経済シナリオの影響をどのように整合的にモデル化を行い，そして，実証分析を実施するのかの方法論 を提案する.

An Evaluation Method of the Transport Project by SCGE under the Future Social Economic Scenarios* By Atsushi KOIKE**, Takashi UKON***, Mitsuhiro MIYASHITA**** and Takashi SATO*****

In recent years, the computable general equilibrium analysis which faithfully reproduced the Warlas system has been widely used as the evaluation technique of infrastructure plan. This study aims at performing sensitivity analysis of benefit evaluation for the road investment in consideration of a future social economy environmental change such as the population reduction and the economic growth of East Asia area in the future.

Specifically, it suggests the methodology to model the influence of a future social economic scenario conformably to the conventional spatial general equilibrium model and to carry out the actual empirical analysis. 